\title{
The Boggulakonda Gabbros, Prakasam District, Andhra Pradesh, India: A Rich Source of Building Material
}

\author{
M. Maria Kumar ${ }^{1}$, G. Vamshi Krishna ${ }^{2}$, S. V. Bhaskar Reddy ${ }^{3}$, \\ R. Anil Kumar ${ }^{4}$ and J. Ratnakar ${ }^{1}$ \\ Department of Geology, Osmania University, Hyderabad - 500007 \\ Department of Applied Geochemistry, Osmania University, Hyderabad-500007 $7^{2}$ \\ Department of Civil Engineering, CMR Technical Campus, Hyderabad. ${ }^{3}$ \\ Department of Civil Engineering, JNTU College of Engineering, Hyderabad ${ }^{4}$
}

\begin{abstract}
Selection of suitable building material for construction of civil structures, irrespective of size, is of utmost importance because the strength and longevity of structure depends on physical and chemical properties of earthy material such as porosity, permeability, structure, texture, grain size, hardness, colour, mineralogy and whole rock chemical composition. In general, igneous rocks serve as the best earthy construction materials because of their physical and chemical properties. Since the igneous rocks are primary rocks which are formed by solidification of magma over varying temperature and pressure conditions, they show variation in colour, texture, mineralogy and hardness. An important igneous rock called 'gabbro' which forms the lower crust (the upper layer of earth's interior upto $36 \mathrm{~km}$ depth), is one of the best material for civil construction work. Gabbros are dark coloured (melanocratic) intrusive igneous rocks with coarse grained texture formed at deep seated conditions in the crust. The gabbro plutons of Prakasam alkaline rock province are emplaced within the Precambrian amphibolite and granite gneiss and their emplacement in tectonically controlled. Boggulakonda is one area in the Praksam District that is occupied by gabbroic rocks. The province has experienced four episodes of folding. The F3 fold axis trending NNE-SSW coincides with the orientation of the gabbro plutons. Gabbro has a variety of uses in the construction industry. It is used for everything from crushed stone base materials at construction sites to polished stone counter tops and floor tiles. Gabbros are known to contain economic mineral deposits. Gabbros containing significant amounts of the mineral ilmenite are mined for their titanium content. Elsewhere, gabbros are mined to yield nickel, chromium and platinum.
\end{abstract}

Keywords: Gabbro, Igneous rock, Magma, Earth's Crust, Province, Building Material, Boggulakonda, Prakasam District, Andhra Pradesh.

\section{Introduction}

Earthy building material can be defined as 'any hard or soft material formed by natural processes of magmatism, sedimentation, metamorphism and weathering of rocks over geological time and space'. The products of these processes include igneous rocks (formed from magma and lava including plutonic, hypabyssal and volcanic rocks), sedimentary rocks (formed by weathering, transportation and deposition of sediments including clastic and non-clastic rocks), metamorphic rocks (formed by regional and contact metamorphism including granulites, amphibolites, greenschists, glaucophane schists, zeolites, hornfelses and marbles of various types). Among all the igneous rocks, a plutonic rock called 'gabbro' (and its hypabyssal equivalent 'dolerite') may be considered as an important 'earthy building material' that has been variously described as 'black granite', 'galaxy granite' etc. Gabbroic rocks occur in abundance in Prakasam District of Andhra Pradesh. The igneous intrusive rocks that formed during Mesoproterozoic-Neoproterozoic period (1600-542 million years) in the Prakasam District of Andhra Pradesh were identified to define an igneous province called 'Prakasam alkaline rock province' (see Fig. 1; Table 1) by Professor Dr. Dr. Chervala Leelanandam (Dept of Geology, Osmania University, Hyderabad), the doyan of Indian Geology, in 1981 and explained in detail in 1989 [1,2]. 


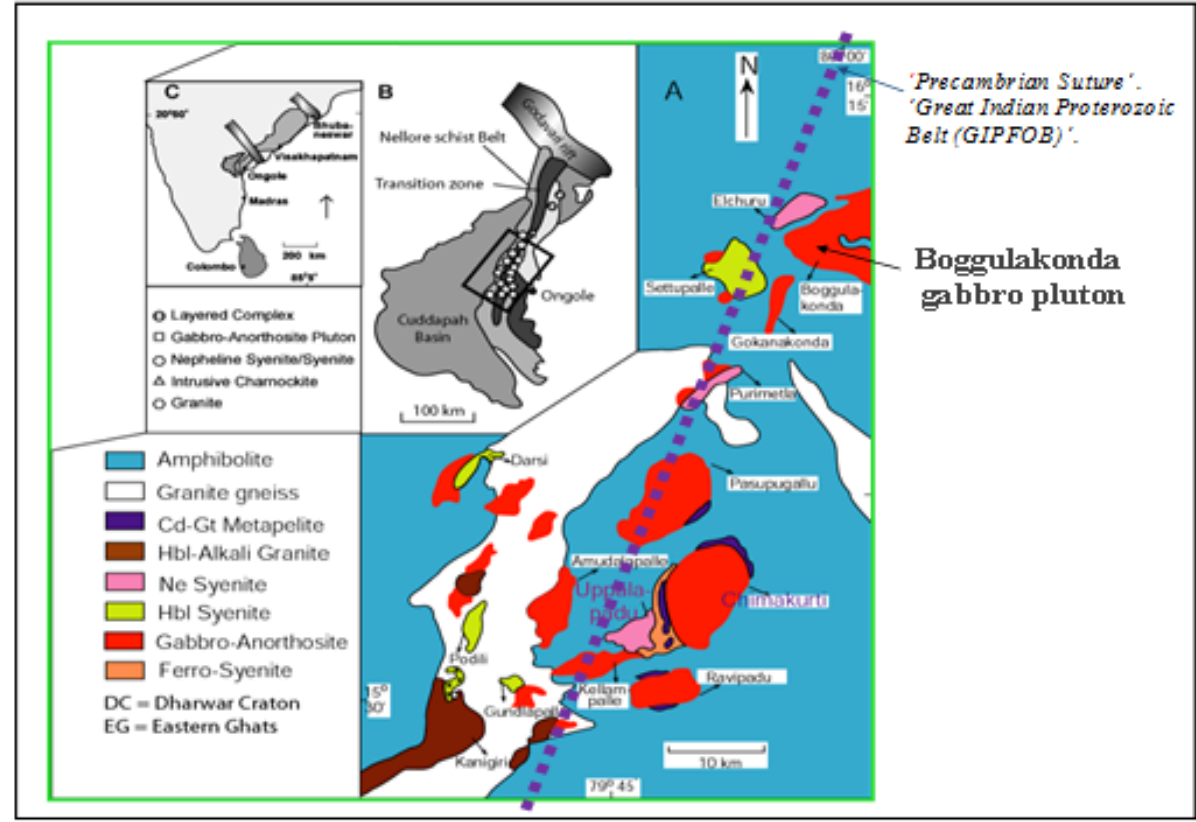

Fig. 1.Geological map showing 'Prakasam alkaline rock province $[1,2,3,4,5]$ showing position of 'Boggulakonda pluton'.

The gabbro plutons of Boggulakonda, Settupalle, Purimetia, Pasupugallu and Chimakurti in the Prakasam alkaline province (PAP) in Andhra Pradesh $[3,4]$ occur in a narrow zone (east of the Cuddapah basin) within the Precambrian amphibolites and granitic gneisses (see Fig. 1). The plutons are emplaced into preheated country rocks as either crystal mushes and multiple intrusive pulses or convective stirring. The chief rock types of the plutons are gabbro, norite, anorthosite, troctolite and rare pyroxenite. The most common use of gabbro is as a crushed stone or aggregate in construction projects including roads. It can also be used as a brittle polish gabbro for cemetery markers, floor tiles, facing stone and dimension stone.

Table 1. Part of 'geological timescale' showing the Precambrian period and the stratigraphic position of the 'Boggulakonda gabbros' and the Prakasam alkaline province.

\begin{tabular}{|c|c|c|c|c|}
\hline Period & Eon & Era & Age (Ma) & Rock types \\
\hline \multirow{5}{*}{ Precambrian } & Proterozoic & Paleoproterozoic & $1600-2500$ & $\begin{array}{l}\text { Igneous, sedimentary and metamorphic } \\
\text { rocks including granulites, } \\
\text { amphibolites, greesnschists, hornfelses, } \\
\text { kimberlites, gabbros, anorthosites, } \\
\text { nepheline syenites, granites, dolerites, } \\
\text { lamprophyres. } \\
\text { 'Prakasam alkaline rock province' } \\
\text { 'Boggulakonda gabbros'. }\end{array}$ \\
\hline & \multirow{4}{*}{ Archaean } & Neoarchean & $2500-2800$ & \multirow{4}{*}{$\begin{array}{l}\text { Metaigneous and sedimentary rocks } \\
\text { including granite gneisses, schists, } \\
\text { greenstone bel ts, iron formations } \\
\text { younger granites dykes etc }\end{array}$} \\
\hline & & Mesoarchaean & $2800-3200$ & \\
\hline & & Paleoarchaean & $3200-3600$ & \\
\hline & & Eoarchaean & $3600-4000$ & \\
\hline
\end{tabular}




\section{Origin of igneous rocks}

The mineral composition of an igneous rock is determined by the chemical composition of the magma from which formed. Two major types of 'primary magmas' were existed at the time of formation of the earth and all types of igneous rocks were derived from them. They are 'acid' and 'basic' types [5]. It is now agreed by many that a natural geological process called 'differentiation' of magma is responsible for the derivation of different types of igneous rocks including gabbros and gabbroic rocks.

\section{Magma types and differentiation}

Magma which is rich in $\mathrm{Si}, \mathrm{Na}$ and $\mathrm{K}$, and poor in $\mathrm{Ca}, \mathrm{Mg}$ and $\mathrm{Fe}$ is called "acid magma'. Granitic rocks form from acidic magmas. On the other hand, magma which is rich in $\mathrm{Ca}, \mathrm{Mg}$ and $\mathrm{Fe}$, and poor in $\mathrm{Si}, \mathrm{Na}$ and $\mathrm{K}$, is called 'basic magma'. Gabbroic rocks, dioritic rocks, syenitic rocks and granitic rocks can form from basic magmas under plutonic conditions. This process by which the a single basaltic magma splits up into fractions that give rise to series of rocks given above, is called 'differentiation'" magma.

\section{What is gabbro?}

Gabbro is a coarse grained, melanocratic, intrusive igneous rock. It is usually black or dark green in colour and composed mainly of the minerals plagioclase and augite. It is the most abundant rock in the deep crust.

\subsection{Position of gabbros among common igneous rock groups}

Table 2 shows the mineralogy and silica content of various igneous rocks that are commonly associated in various geological settings. It shows the position of 'gabbro' relative to other rocks in this classification scheme.

Table 2. Position of 'gabbro' relative to other igneous rocks.

\begin{tabular}{|c|c|c|c|c|c|c|c|c|}
\hline & \multicolumn{3}{|c|}{ Oversaturated } & \multicolumn{2}{|l|}{ Saturated } & \multicolumn{3}{|c|}{ Undersaturated } \\
\hline & \multicolumn{3}{|c|}{ Quartz feldspars } & \multicolumn{2}{|l|}{ Feldspars } & \multicolumn{3}{|c|}{ Plagioclase / Feldspathoids } \\
\hline \multirow[t]{4}{*}{$\begin{array}{l}\text { Felsic } \\
\text { Mafelsic } \\
\text { Mafic }\end{array}$} & Quartz & $\begin{array}{l}\text { Predominant } \\
\text { Orthoclase }\end{array}$ & $\begin{array}{l}\text { Predominant } \\
\text { Plagioclase }\end{array}$ & $\begin{array}{l}\text { Predominant } \\
\text { Alkali } \\
\text { feldspar } \\
\text { (Or, Ab) }\end{array}$ & $\begin{array}{l}\text { Predominant } \\
\text { Soda lime } \\
\text { Plagioclase }\end{array}$ & $\begin{array}{l}\text { Predominant } \\
\text { Lime } \\
\text { Plagioclase }\end{array}$ & $\begin{array}{l}\text { Feldspart } \\
\text { Felspathoids }\end{array}$ & Felspathoids \\
\hline & $\begin{array}{l}\text { Igneous } \\
\text { Quartz } \\
\text { Veins }\end{array}$ & Granite & $\begin{array}{l}\text { Granodionite } \\
\text { (Tonalite) }\end{array}$ & Syenite & Dionite & $\begin{array}{l}\text { Anorthosite } \\
\text { "Gabbro" }\end{array}$ & $\begin{array}{l}\text { Nepheline } \\
\text { Syenite }\end{array}$ & \\
\hline & & $\begin{array}{l}\text { Granophyre } \\
\text { Felsite }\end{array}$ & Pitchstone & $\begin{array}{l}\text { Aplites } \\
\text { Porphyries }\end{array}$ & Lamprophyres & Dolente & & \\
\hline & & $\begin{array}{l}\text { Rhyolite } \\
\text { Obsidian }\end{array}$ & $\begin{array}{l}\text { Dacite } \\
\text { Pitchstone }\end{array}$ & Trachyte & Andesite & $\begin{array}{l}\text { Basalt } \\
\text { Trachylyte }\end{array}$ & Phonolite & $\begin{array}{l}\text { Basalt } \\
\text { Lucite } \\
\text { Basalt }\end{array}$ \\
\hline $\begin{array}{l}\text { Average } \\
\text { Silica \% }\end{array}$ & 90 & 72 & 66 & 59 & 57 & 48 & 54.5 & 43 \\
\hline
\end{tabular}

\subsection{The gabbro plutons}

Gabbros are the most widespread plutonic igneous rocks in the earth's crust. They occur in all the geological environments through space and time. Layered gabbro intrusions such as Skaergaard and Bushveld [6] record processes which operated within basic magma chambers.

\section{The gabbros of Prakasam alkaline province}

The Prakasam alkaline province (PAP) is a Proterozoic intra-plate, sub-alkaline and alkaline igneous province in the Prakasam district of Andhra Pradesh [1, 2]. The PAP is composed chiefly of gabbro plutons (sub-alkaline) and syenite and granite intrusive (alkaline or calc-alkaline). The available $\mathrm{Rb}$-Sr isotopic ages of the alkaline complexes of PAP range from 1369 to 1098 Million years (Ma). It is considered that the basic magmatism has predated the alkaline magmatism [5].

\subsection{Colour and texture of Boggulakonda gabbros}

The gabbroic rocks are mesocratic (medium coloured) to melanocratic ( black colured) and medium- to coarsegrained. Under the microscope they exhibit ophitic to sub-ophitic, cumulate and hypidiomorphic textures.

\subsection{Mineralogy of Boggulakonda gabbros}

The mineralogy of the Boggulakonda gabbros is given in Table 3. The rocks are essentially composed of clinopyroxene and plagioclase with minor amphibole, occasional biotite and small quantities of opaques, apatite and others.

Table 3. Mineralogy of Boggulakonda gabbros.

\begin{tabular}{|l|l|l|}
\hline Essential minerals & Minor minerals & Accessory minerals \\
\hline $\begin{array}{l}\text { Clinopyroxene + plagioclase } \\
\pm \text { (olivine, orthopyroxene). }\end{array}$ & Amphibole & Opaques, apatite, sphene, calcite, spinel, \\
\hline
\end{tabular}


The Boggulakonda Gabbros, Prakasam District, Andhra Pradesh, India: A Rich Source of Building

\subsection{Rock types of Boggulakonda pluton}

The gabbros of Boggulakonda are classified into melagabbro, olivine gabbronorite, gabbro Norite, leucogabbro and anorthosite on the basis of mineral associations and their relative abundance in these rocks.

\subsection{Petrochemistry of Boggulakonda gabbros}

The ranges of major element oxides (wt. \%) in the gabbro plutons of Prakasam alkaline province (PAP) including the boggulakonda gabbros are given in Table 4.

Table 4. Ranges of major element oxides (wt. \%) in the gabbro plutons of Prakasam alkaline province (PAP) including the Boggulakonda gabbros.

\begin{tabular}{|l|l|}
\hline Oxide & Weight \% \\
\hline $\mathrm{SiO} 2$ & $42.37-52.03$ \\
\hline $\mathrm{TiO} 2$ & $00.08-01.71$ \\
\hline $\mathrm{Al} 2 \mathrm{O} 3$ & $04.24-23.46$ \\
\hline $\mathrm{Fe} 2 \mathrm{O} 3$ & $00.39-03.38$ \\
\hline $\mathrm{FeO}$ & $02.70-12.00$ \\
\hline $\mathrm{MnO}$ & $00.04-00.25$ \\
\hline $\mathrm{MgO}$ & $03.32-23.20$ \\
\hline $\mathrm{CaO}$ & $09.52-14.56$ \\
\hline $\mathrm{Na} 2 \mathrm{O}$ & $00.40-04.85$ \\
\hline $\mathrm{K} 2 \mathrm{O}$ & $00.08-01.66$ \\
\hline $\mathrm{P} 2 \mathrm{O} 5$ & $00.04-00.30$ \\
\hline
\end{tabular}

\section{Boggulakonda gabbros as building material}

The Boggulakonda gabbros in Prakasam District of Andhra Pradesh State, India is a rich source of strong earthy building material and economic metals.

\subsection{Smooth slabs}

Boggulakonda gabbros take smooth polishing due their uniform texture and gain size variation. They can also be used as table tops and wall elevations (like the one shown in Fig. 2). Orbicular varieties of gabbro, occur rather rarely in the Boggulakonda pluton, can be used as paving stone. It is also used in kitchens and their countertops. It has also seen some use as a garden paving stone. Because of its resistance to most weathering, gabbro can be used as a material for lake and ocean break walls, or the retaining walls used to help prevent coastal erosion and flooding.

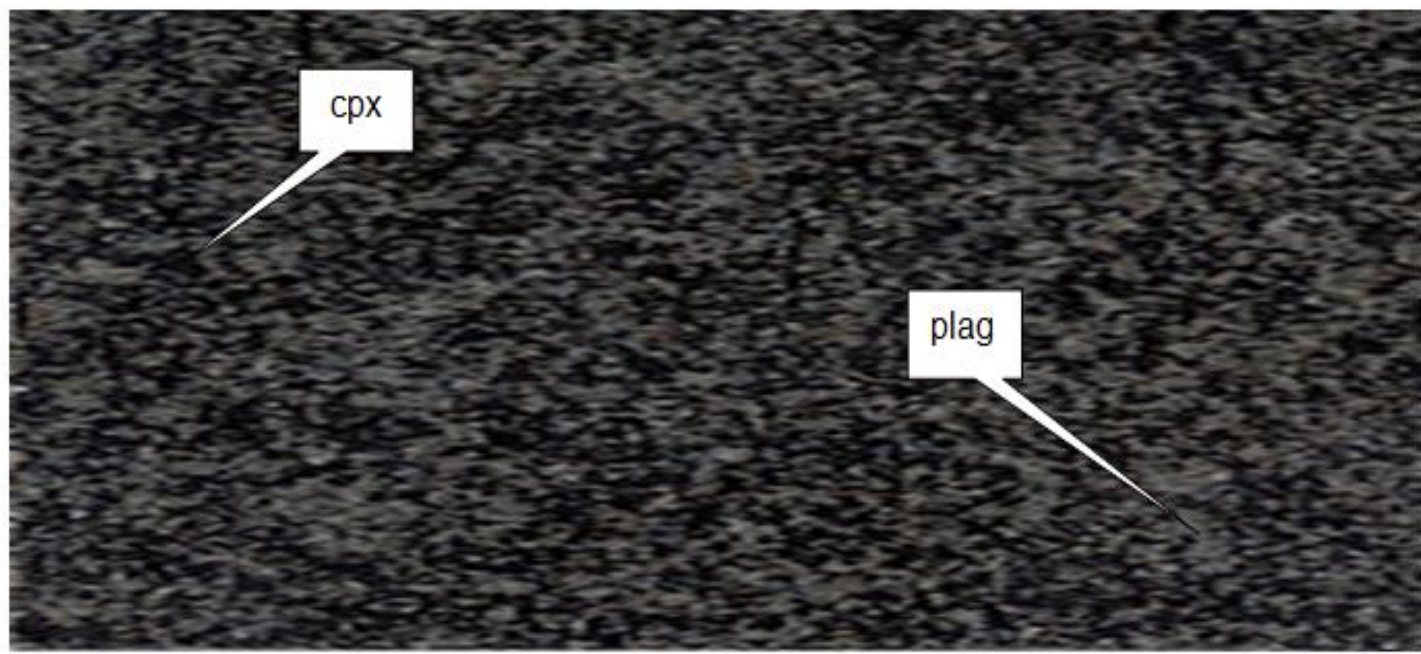

Fig. 2. Smooth polished surface of gabbro. Grey portions represent plagioclase (plag) and dark portions represent clinopyroxene (cpx).

\subsection{Source of metals}

Gabbros contain rich economic metal deposits such as chromium, nickel, and copper sulfides, The amount of these minerals is globally variable depending on the individual minerals that formed each gabbro intrusion. Gabbro contains mineral ilmenite which can be mined for its titanium content. Gabbros and associated ultramafic rocks contain valuable amounts of chromium, nickel, cobalt, gold, silver, platinum and copper sulfides. 
The Boggulakonda Gabbros, Prakasam District, Andhra Pradesh, India: A Rich Source of Building

\subsection{Crush-stone}

Crushed stone produced out of Boggulakonda gabbros is ideal for strong building material especially for construction of water-based projects due to its low water absorption rate. Gabbros can also be used for road construction as it significantly increases the life of roads. Crushed stone made of gabbro-diabase does not require expensive additives that are used for crushed granite. Some salient engineering properties of gabbroic rocks is given in Table 5 for ready reference.

Table 5.Some engineering properties of gabbros

\begin{tabular}{|l|l|l|}
\hline Frost Resistance & Bulk Density & Compressive Strength \\
\hline F300 & $1.5 \mathrm{t} / \mathrm{m} 3$ & $375 \mathrm{MPa}$ \\
\hline
\end{tabular}

\subsection{Decorative stone}

Gabbros with orthopyroxene especially 'bronzite' are called galxy granites. They are rarely developed in Boggulakonda area. In general, gabbros form good attractive and durable decorative stone.

\section{Recommendations and conclusion}

Gabbro is an igneous rock formed from magma at greater depths but now exposed at the surface due to upliftment and erosion of overburden. Prakasam alkaline province is broad area in which gabbros are present at various localities including Boggulakonda. These gabbros are very useful for all constructions as building stone including decorations irrespective of their size as they are very hard, durable and crystalline rocks with zero porosity and permeability, when they are insitu and fresh.

\section{Acknowledgements}

MMK and GVK thank the HoDs' of Geology and Applied Geochemistry Departments, Osmania Univeristy, for lab facilities and encouragement during the progress of this work.

\section{References}

[1] Leelanandam, C., An alkaline province in Andhra Pradesh. Curr. Sci., 1981, v. 49, pp. 550-551.

[2] Leelanandam, C., Some observations on the alkaline province of Andhra aPradesh. Curr. Sci., v. 50, pp. 799-802.

[3] Vijaya Kumar, K. and Ratnakar, J., Petrogenesis of the Ravipadu gabbro pluton, Prakasam province, Andhra Pradesh. Jour. Geol. Soc. India, 2001, pp. 113-140.

[4] Vijaya Kumar, K., Frost, C. D., Frost, B. R. and Chamberlin, K. R., The Chimakurti, Errakonda and Uppalapadu plutons, Eastern Ghats belt, India: An unusual association of tholeiitic and alkaline magmatism. Lithos, 2007, v. 97, pp. 30-57.

[5] Ratnakar, J. and Lelanandam, C., The Purimetla gabbros. Prakasam District, Andhra Pradesh, India. Proc. Indian Acad. Sci. (EPSL), 1985, v. 94, pp. 305-313.

[6] Wager, L. R. and Brown, G. M., Layered igneous rocks. Oliver and Boyd Ltd., Edinburgh, 588p.

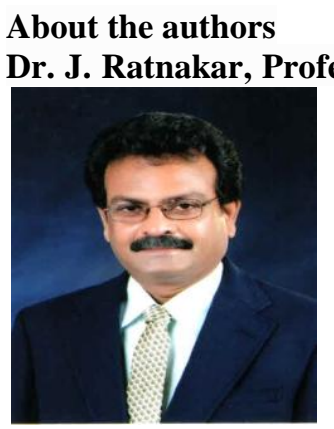

essor (Retired), Department of Geology, Osmania University, Hyderabad, is specialized in igneous petrology and geochemistry of gabbros, alkaline rocks and granites. He has 33 years of teaching and 37 years of research experience in geology and geological materials. His interests lie in engineering geology in relation to mineralogy, petrology and geochemistry. He was the recipient of 'Gold Medal' for Science faculty first position in M Sc Geology, Osmania University in 1979, 'Best Research Paper Award' by Geological-Mining-Metallurgical Society of India in 1983, 'Young Scientist Award' by AP Academy of Sciences in 1989, and national 'UGC Career (Research) Award' in Earth Sciences in 1994, and receipient of 'Srimati Kethiraju Venkata Subbamma and Sri Subba Rao Medal' for best contributions in geochemistry during the last decade' by Indian Society of Applied Geochemists (ISAG) in 2016. He was Member of Geoscience Advisory Council $(G A C)$, Ministry of Mines, Government of India (2012-2016). . He was the Principal Investigator of DST and UGC Major Research Projects on Ravipadu gabbro-anorthosite pluton and Chanduluru gabbro-syenite complex, Andhra Pradesh. He was UGC Career Awardee at University of Wyoming, Laramie, USA and worked with Prof. B. Ronald Frost on EPMA (Jeol Probe) during 1996-97. Prof. J. Ratnakar around 100 Research publications, attended / organized around 50 Seminars and Conferences, supervised $5 \mathrm{PhDs}$ ' and guided $18 \mathrm{M}$. Sc theses, reviewed two books, visited labs of University of Quebec, Montreal, Canada, and EPMA and ICPMS Labs in the Dept of Geology, Carleton University, Ottawa, Canada at the invitation of Prof. Keith Bell in 2006. He was a Member of Executive Committee of Indian Society of Applied Geochemists (ISAG), Hyderabad 
during 2008-11 and is presently on its Editorial Board as Member. Prof. Ratnakar is the Fellow of Indian Society of Applied Geochemists (Hyderabad), Geological Society of India (Bangalore), Mineralogical Society of India (Mysore), Indian Academy of Geoscience (Hyderabad), Founder Member of Telangana Academy of Sciences (Hyderabad, T.S.), and Andhra Pradesh Academy of Sciences (Amaravathi, A. P.).

M. Maria Kumar, a research scholar in Department of Geology, Osmania University, Hyderabad, is

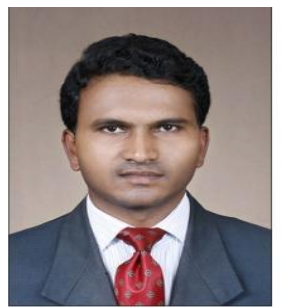
specialized in igneous petrology and geochemistry of gabbros and other rocks. He has 2 years of teaching, 2 years of Industrial and 4 years of research experience in geology and geological materials.

*** 